\title{
Insufficient intake of alpha-linolenic fatty acid (18:3n-3) during pregnancy and associated factors
}

\author{
Ingestão insuficiente de ácido graxo \\ alfa-linolênico (18:3n-3) durante \\ a gestação e fatores associados
}

Letícia Garcia VASCONCELOS ${ }^{1}$

Caroline de Barros GOMES ${ }^{2}$

Maíra Barreto MALTA ${ }^{3}$

Isaias DICHI ${ }^{4}$

Maria Helena D’Aquino BENÍCIO

Maria Antonieta de Barros Leite CARVALHAES 5

\section{A B S T R A C T}

\section{Objective}

To analyze alpha-linolenic fatty acid intake in two cohorts of pregnant women, and to identify factors associated with alpha-linolenic acid intake.

\section{Methods}

This is a cohort study involving pregnant women with low obstetric risk $(\mathrm{N}=353)$ in public health system from a municipality of São Paulo state, Brazil. In each trimester, two 24-hour food recalls were collected. Descriptive analyses of dietary lipid profiles were performed, followed by a multiple comparison test. According to the trimester of pregnancy, differences were assessed using the mean difference test. To evaluate the adequacy of

\footnotetext{
1 Universidade Estadual Paulista Júlio de Mesquita Filho, Faculdade de Medicina, Programa de Residência Multiprofissional em Saúde do Adulto e do Idoso. Botucatu, SP, Brasil.

2 Universidade Estadual Paulista Júlio de Mesquita Filho, Faculdade de Medicina, Programa de Pós-Graduação em Saúde Coletiva. Botucatu, SP, Brasil.

${ }^{3}$ Universidade de São Paulo, Faculdade de Saúde Pública, Departamento de Nutrição. São Paulo, SP, Brasil.

${ }^{4}$ Universidade Estadual de Londrina, Centro de Ciências da Saúde, Departamento de Clínica Médica. Londrina, PR, Brasil.

5 Universidade Estadual Paulista Júlio de Mesquita Filho, Faculdade de Medicina, Departamento de Enfermagem. Av. Prof. Montenegro, s/n., Distrito de Rubião Júnior, 18618-970, Botucatu, SP, Brasil. Correspondência para/Correspondence to: MABL CARVALHAES. E-mail: <carvalha@fmb.unesp.br>.

Support: São Paulo Research Foundation (Research grant Process n 2011/18579-0; Scientific Initiation Grant: Process $\left.n^{\circ} 2014 / 2563\right)$.
} 
linoleic fatty acid and alpha-linolenic acid intake, the adequate intake test was used. The association between alpha-linolenic acid intake adequacy and maternal characteristics was investigated using a binary logistic regression model.

\section{Results}

Total lipids intake and the percentage contribution to dietary energy met recommended levels. One-third of the diets demonstrated a lower than daily recommended intake of alpha-linolenic acid. Overweight pregnant women were twice as likely to have inadequate alpha-linolenic acid intake. Pregnant women from a more disadvantaged socioeconomic situation had greater risks of inadequate intake.

\section{Conclusion}

Over-intake of lipids is not problematic, but quality is an issue, with one third of the pregnant women and their fetuses exposed to adverse effects due to low intake of omega-3 fatty acids, indicating important nutritional vulnerability in this population.

Keywords: Alpha-linolenic acid. Fatty acids, omega-3. Fatty acids, omega-6. Pregnant women.

\section{RE S U M O}

\section{Objetivo}

Analisar a ingestão ácidos graxos alfa-linolênico e identificar fatores associados à ingestão inadequada em duas coortes de gestantes acompanhadas trimestralmente.

\section{Métodos}

Estudo de coorte com gestantes de baixo risco obstétrico ( $N=353)$ representativas das usuárias da rede pública de saúde de um município paulista. Nos três trimestres gestacionais foram coletados dois recordatórios alimentares de 24 horas. Análises descritivas do perfil lipídico da dieta foram processadas seguidas do teste de comparações múltiplas. As diferenças, segundo trimestre gestacional, foram avaliadas pelo teste de diferença de médias. Para avaliação da adequação do consumo foi utilizada a ingestão recomendável. A associação entre a adequação da ingestão de ácido alfa-linolênico e características maternas foi investigada por meio de modelo de regressão logística binária.

\section{Resultados}

A contribuição percentual de lipídeos totais mostrou-se adequada; 1/3 das gestantes não alcançou a recomendação de ingestão diária de ácido alfa-linolênico. Gestantes com excesso de peso apresentam o dobro de chances de consumo inadequado de ácido alfa-linolênico. Comparadas às gestantes das classes D/E, as pertencentes a classe C têm menores chances de consumo inadequado.

\section{Conclusão}

Não há um problema de excesso de consumo de lipídeos e sim da qualidade destes, cerca de 1/3 das gestantes acompanhadas e seus conceptos estão expostos aos efeitos adversos do baixo consumo de ácidos graxos de cadeia ômega-3 na gestação, indicando importante vulnerabilidade nutricional nessa população.

Palavras-chave: Ácido alfa-linolênico. Ácidos graxos ômega-3. Ácidos graxos ômega-6. Gestantes.

\section{INTRODUCTION}

The gestational period is a phase in which great physiological, psychological and nutritional changes occur. The need for nutrients to supply the growth and development of the fetus increase, and many components of the diet influence the health of both the mother and child [1]. Examples of these nutrients are long-chain Polyunsaturated Fatty Acids (PUFAs) such as alpha-linolenic (omega-3) and linoleic (omega-6) fatty acids, with an important correlation between the levels of PUFA in the fetus and in the mother [2].

Omega-3 fatty acids may act to reduce oxidative stress, which is increased during pregnancy. A review of the literature indicates that omega-3 fatty acids, because of their 
anti-inflammatory and antioxidant function, may have a role in protecting women with pre-gestational obesity against pregnancy complications. In overweight pregnant women, the natural remodeling of adipose tissue is exacerbated, increasing the lipid profile and secretion of adipocytokines, leading to a state of inflammation [3]. Moreover, overweight Brazilian women of childbearing age are becoming increasingly more common [4].

A meta-analysis highlighted the positive influence of higher omega-3 fatty acids intake during pregnancy in reducing the risk of prematurity [5]. A study carried out in Rio de Janeiro with pregnant adolescents found that intake of omega-3 fatty acids was a predictor of the babies' birth weight, and for intake of every 1 gram of omega-3 fatty acids, the baby's weight increased by 74.33 grams [6].

Additionally, studies on outcomes related to the intake of omega-3 fatty acids include the effects on the mother's mental health, with lower intake related to an increased risk of depressive symptoms during gestation [7], and a relationship between a 9:1 ratio of linoleic and alpha-linolenic fatty acids intake and postpartum depression [8]. Docohexanoic acid supplementation during pregnancy was associated with a higher level of attention in children at five years of age [9].

Several studies on the diet of pregnant women have predominantly used the Food Frequency Questionnaire (FFQ) as a tool for assessing consumption. There have been limitations identified in using this tool to evaluate the consumption of food groups among the pregnant population, especially when evaluating food changes throughout the gestational trimesters $[10,11]$.

The objectives of the present study were to analyze the intake of alpha-linolenic and linoleic fatty acids and to identify factors associated with the intake of alpha-linolenic acid in two cohorts of pregnant women.

\section{METHODS}

This is a cohort study, using data obtained from previous research undertaken to determine the effectiveness of a training intervention for primary health care professionals to promote walking during leisure time and five eating practices (none specifically related to lipid intake) for patients attending prenatal appointments. The study was carried out in Botucatu (SP), a city with 140,000 inhabitants, with more than $90 \%$ residing in an urban area, located in the Central region of the state of São Paulo, in Southeastern Brazil.

Further details of the main study are mentioned in a previous publication [12]. Briefly, pregnant women attending in Family Health Units (cohort A) were monitored by trained professionals who promoted the following dietary practices: three servings of fruits, two servings of vegetables, two servings of beans daily (at least five days a week), with occasional consumption of soft drinks or industrially processed cookies. Cohort B comprised pregnant women from Basic Health Units who were assisted by professionals not involved in this training. These women received the usual prenatal care, which follows Ministry of Health guidelines, and further guidelines on healthy eating and physical activity during pregnancy [13].

Based on the tracking/recruitment system adopted, the two cohorts were representative of pregnant women receiving prenatal care in the public primary health care service of the city. Pregnant women were recruited daily from November 2012 to June 2013, with data collection completed in January 2014. All women who completed prenatal enrollment in the Primary Health Care service within this period were invited to participate in the study. Pregnant women aged 18 or over in the first trimester of pregnancy $(<14$ weeks) were eligible for the study. The exclusion criteria were as follows: the presence of diseases or complications identified during the study, such as diabetes, hypertension, 
cardiopathy, or any adverse condition requiring rest or a reduction of physical activity.

The study commenced with 181 pregnant women in cohort $A$ and 172 pregnant women in cohortB. In the first trimester of pregnancy, validated food consumption data were obtained for all the pregnant women initially recruited $(\mathrm{N}=353)$. As the study progressed, seven pregnant women declined to continue participating, and there were further losses due to prenatal setting changes (transferal to private or to high-risk prenatal care), pregnancy terminations, or a change of city, with a refusal rate of $3.0 \%$. In the second and third trimesters of pregnancy, 140 and 134 pregnant women from cohort $A$, and 141 and 133 from cohort B, respectively, were studied.

Six 24-Hour Recalls (24hR) were undertaken, divided into three stages of pregnancy: 1st trimester ( $<14$ weeks), 2nd trimester (24-27 weeks) and 3rd trimester (31-34 weeks). In each trimester, one recall was obtained by an interview at home and the second recall was by telephone interview. Strict care was taken to obtain, on a quarterly basis, a recall related to a weekend or holiday period and another to a weekday.

Dietary recalls were applied using the Multiple Pass Methods method, whereby the interview is conducted in five stages by the interviewer: quick listing, commonly overlooked food listing, meal and time setting, detailed listing, and final review. This method helps the interviewee to remember the previous day's diet and to reduce dietary measurement errors [14]. Information on the consumption of beverages was also obtained in the dietary recall.

The inclusion of food consumption data was recorded in the Nutrition Data System for Research software, version 2010 (University of Minnesota, Minneapolis, United States). Prior to inclusion in the software, standardization and quantification of foods and preparations (grams or milliliters) were performed. In order to correct and minimize errors, specifically around the underestimation or overestimation of the intake, a consistency analysis was performed after typing each recall. This analysis verified the foods and preparations typed, with special attention paid to the units of measurement and the presence of outliers for portions, weights, energy, and nutrients.

In addition to the recalls, socioeconomic, demographic, obstetric history, and current pregnancy data were collected by the interviewer during the home visit to further assist in characterizing the population.

Descriptive analyses on lipid intake in each cohort and gestational trimester, and for the group of pregnant women (cohort $A$ and cohort B), were processed using a generalized linear model, with gamma distribution for the data that presented an asymmetric distribution. This was followed by a multiple comparisons test to verify differences in the quarterly intake of energy, lipids, saturated fatty acids, monounsaturated fatty acids, polyunsaturated fatty acids, alpha-linolenic acid, and linoleic acid, and the ratio between the latter: the linoleic/ alpha-linolenic ratio. The ratio was obtained by dividing the intake of linoleic and alpha-linolenic fatty acids, and described according to the gestational trimester. The differences according to gestational trimester, in relation to a single cohort, were evaluated by a means difference test.

To evaluate an adequate intake of linoleic and alpha-linolenic fatty acids, the adequate intake value of $1.4 \mathrm{~g}$ was used, which is applied when Recommended Dietary Allowances and Estimated Average Requirements values are not established [15]. The adequate intake value represents an intake that is possibly greater than the true need. It can be presumed that intake values above adequate intake reflect an adequate intake, while values below may or may not be adequate, without having to draw definite conclusions on the matter [16]. In the present study, therefore, the percentage of pregnant women with adequate intake was 
estimated, considering adequate intake as the reference. Dietary Reference Intakes were used to evaluate total lipid intake and their percentage contribution to dietary energy [17].

The association between the adequacy of alpha-linolenic acid intake and maternal characteristics (years of schooling, age, socioeconomic status, working outside the home, living with a partner, smoking before pregnancy, drinking alcohol before pregnancy, number of births, white skin color, pregestational nutritional status) was investigated using a binary logistic regression model. The dependent variable/outcome was dichotomized into adequate intake (above adequate intake) and inadequate intake (below adequate intake). Initially, regression analysis was performed with each of the exposure variables and outcome, including cohort and trimester variables as adjustment variables. Energy intake increases in the second trimester, and the effect of energy on the chance of adequate/inadequate intake of alpha-linolenic acid was aimed to be removed with the trimester variable in the analysis. The cohort variable in the analyses aimed to address the confounding factor of professionals who assisted cohort A women and who were trained to promote healthy eating practices, although none specifically related to lipid intake.

All variables with $p<0.20$ were considered potential candidates for the final model. The cohort and gestational trimester variables were maintained in the final model regardless of the $p$-value.

All tests were performed in the Statistical Package for the Social Science for Windows (SPSS, Chicago, Illinois, United States), version 20.0 , considering $p<0.05$ as a level of statistical significance.

The matrix project was submitted to the Research Ethics Committee of the Medical School of Botucatu, with approval granted on 05/09/2011 (CEP: 3989/2011). The authorization of the subproject to analyze the food consumption of pregnant women was obtained on 07/07/2014 (CAAE: 32407314.0.0000.5411). Before the first data collection, all the pregnant women were informed about the project and study procedures, and Signed an Informed Consent.

\section{RES U L T S}

Table 1 shows the socioeconomic, demographic, obstetric, and nutritional status characteristics of the pregnant women studied. Most pregnant women were between 20 and 29 years of age (59.5\%), had had 11 years or more of study $(49.3 \%)$, belonged to socioeconomic class C (68.1\%), did not work outside the home (51.8\%), lived with a partner (73.9\%), were primiparous $(42.2 \%)$, had white skin color $(64.3 \%)$, and reported no tobacco use $(74.5 \%)$ or alcohol consumption (61.5\%) prior to pregnancy. The most prevalent pre-gestational nutritional status was normal weight $(47.9 \%)$, but close to overweight values (47.0\%).

Table 2 shows the total intake of energy, lipids, and saturated, monounsaturated, and polyunsaturated fatty acids according to the gestational trimester. The total intake of energy, lipids, saturated and monounsaturated fatty acids increased from the first to the second trimester and there was no difference between the second and third trimesters. The mean intake of polyunsaturated fatty acids also increased from the first to the second gestational trimester, but without statistically significant differences between the third and the other trimesters.

Considering all the recalls analyzed, the mean energy intake during pregnancy was 1873.43 (Standard Deviation-SD=654.99) kcal, with 64.59 (SD=28.87) grams of lipids, 21.75 $(S D=11.19)$ grams of saturated fatty acids, 21.43 ( $S D=0.54$ ) grams of monounsaturated fatty acids and 15.77 ( $S D=7.31$ ) grams of polyunsaturated fatty acids. The intake of lipids corresponded to $31.2 \%$ of the energy total, comprising $10.4 \%$ of saturated fatty acids, 
Table 1. Socioeconomic, demographic, obstetric, and nutritional status characteristics of pregnant women $(\mathrm{N}=353)$. Botucatu (SP), 2012-2014.

\begin{tabular}{|c|c|}
\hline Characteristics & $\%$ \\
\hline \multicolumn{2}{|l|}{ Age (years) } \\
\hline $18-19$ & 15.0 \\
\hline $20-30$ & 59.5 \\
\hline$>30$ & 25.5 \\
\hline \multicolumn{2}{|c|}{ Level of education (years) } \\
\hline$\geq 11$ years & 49.3 \\
\hline $8-11$ years & 28.9 \\
\hline$<8$ years & 21.8 \\
\hline \multicolumn{2}{|c|}{ Socioeconomic classification ${ }^{\mathbf{a}}$} \\
\hline B & 9.9 \\
\hline $\mathrm{C}$ & 68.1 \\
\hline $\mathrm{D} / \mathrm{E}$ & 22.0 \\
\hline \multicolumn{2}{|c|}{ Works outside the home } \\
\hline Yes & 48.2 \\
\hline No & 51.8 \\
\hline \multicolumn{2}{|c|}{ Lives with a partner } \\
\hline Yes & 73.9 \\
\hline No & 26.1 \\
\hline \multicolumn{2}{|c|}{ Number of births ${ }^{\mathbf{b}}$} \\
\hline 0 & 42.2 \\
\hline 1 & 27.8 \\
\hline$\geq 2$ births & 30.0 \\
\hline \multicolumn{2}{|l|}{ White skin color } \\
\hline Yes & 64.3 \\
\hline No & 35.7 \\
\hline \multicolumn{2}{|c|}{ Use of tobacco before pregnancy ${ }^{d}$} \\
\hline Yes & 25.5 \\
\hline No & 74.5 \\
\hline \multicolumn{2}{|c|}{ Alcohol consumption before pregnancy } \\
\hline Yes & 38.5 \\
\hline No & 61.5 \\
\hline \multicolumn{2}{|c|}{ Pre-gestational nutritional status ${ }^{f}$} \\
\hline Underweight & 5.0 \\
\hline Normal weight & 47.9 \\
\hline Excess weight & 28.7 \\
\hline Obese & 18.3 \\
\hline
\end{tabular}

Note: ${ }^{\mathrm{a}}$ Missing information about purchasing power $(\mathrm{n}=8)$; ${ }^{\mathbf{b}}$ Missing information about parity $(n=3)$; 'Missing information about ethnicity $(n=3) ;{ }^{d}$ Missing information about tobacco usage $(n=3)$; ${ }^{\mathbf{e}}$ Missing information about alcohol consumption $(n=3)$; ${ }^{f_{M}}$ Missing information about body mass index $(n=15)$.

$10.3 \%$ of monounsaturated fatty acids, and $7.6 \%$ of polyunsaturated fatty acids (data not shown).

The rate of linoleic acid and alphalinolenic acid intake, and the ratio between them, according to each gestational trimester, is presented in Table 3. There was an increase in linoleic acid intake from the first to the second gestational trimester and no difference between the second and third trimesters. Despite an increase in the intake of alpha-linolenic acid as pregnancy advanced, there was only a significant difference between the first and third trimesters. The mean ratio between these fatty acids did not present a statistically significant difference between the gestational trimesters.

The mean intake of linoleic fatty acid was 13.74 (SD=6.49) grams, having a minimum intake of 1.33 grams and a maximum intake of 50.46 grams. The mean alpha-linolenic acid intake was 1.80 (SD=0.81) grams, with a minimum intake of 0.14 grams and a maximum of 6.97 grams. The ratio of linoleic fatty acid to alpha-linolenic had a mean of $7.73(S D=1.82)$, with a minimum and maximum ratio of 2.72 and 34.19 , respectively (data not shown in the table).

Considering adequate intake, 32.5\% of the diets presented values of alpha-linolenic acid intake below recommended levels. Table 4 shows the results of logistic regression analyses between maternal characteristics and inadequacy of alpha-linolenic acid intake $(<1.4 \mathrm{~g} / \mathrm{d})$, always adjusted by trimester and cohort. Socioeconomic status and pregestational nutritional status were associated with inadequate intake of alpha-linolenic acid independently of each other, of the trimester and the cohort to which the pregnant woman belonged. Obese pregnant women were twice as likely to have inadequate intake of linoleic fatty acid in comparison with normal weight pregnant women (Oddes Ratio-OR $=2,080$; 95\% Confidence Interval-95\% $\mathrm{Cl}=1,414-3,061$, $p=0.003)$. Pregnant women in classes $B$ and $C$ had less chance of inadequate intake compared to those in classes $D$ and $E(p=0.019)$, however the results reached statistically significant levels only for those in class $C$. 
Table 2. Energy intake and lipid profile of pregnant women, according to gestational trimester. Botucatu (SP), 2012-2014'.

\begin{tabular}{|c|c|c|c|c|c|c|}
\hline \multirow{2}{*}{ Diet component } & \multicolumn{2}{|c|}{ 1st trimester $(n=353)$} & \multicolumn{2}{|c|}{ 2nd trimester $(n=281)$} & \multicolumn{2}{|c|}{ 3rd trimester $(n=267)$} \\
\hline & Mean & $S D^{2}$ & Mean & $S D^{2}$ & Mean & $S D^{2}$ \\
\hline Energy (kcal) & 1758.42 & $676.63^{a}$ & 1961.93 & $583.88^{\mathbf{b}}$ & 1931.26 & $676.89^{b}$ \\
\hline Lipids (g) & 59.82 & $28.35^{\mathrm{a}}$ & 68.23 & $26.42^{\mathbf{b}}$ & 67.02 & $31.17^{\mathbf{b}}$ \\
\hline Saturated fatty acids (g) & 19.70 & $10.59^{a}$ & 23.37 & $10.63^{\mathbf{b}}$ & 22.72 & $12.14^{\mathbf{b}}$ \\
\hline Monounsaturated fatty acids (mg) & 19.70 & $10.23^{a}$ & 22.69 & $9.83^{\mathbf{b}}$ & 22.27 & $11.36^{\mathbf{b}}$ \\
\hline Polyunsaturated fatty acids (mg) & 15.17 & $7.58^{\mathrm{a}}$ & 16.16 & $6.72^{\mathbf{b}}$ & 16.13 & $7.50^{\mathrm{ab}}$ \\
\hline
\end{tabular}

Note: ${ }^{1}$ Data on the two cohorts of pregnant women (A and B) together; ${ }^{2}$ Means followed by the same letter do not differ according to the means difference test.

SD: Standard Deviation.

Table 3. Intake of linoleic fatty acid (18:2n-6), $\alpha$-linolenic acid (18:3n-3) and linoleic/alpha-linolenic fatty acid ratio, according to gestational trimester. Botucatu (SP), 2012-2014'.

\begin{tabular}{|c|c|c|c|c|c|c|c|c|c|}
\hline \multirow{2}{*}{ Type of fatty acid/6/3 ratio } & \multicolumn{3}{|c|}{ 1st trimester $(n=353)$} & \multicolumn{3}{|c|}{ 2nd trimester $(n=281)$} & \multicolumn{3}{|c|}{ 3rd trimester $(n=267)$} \\
\hline & M & $S D^{2}$ & Min.-Max. & M & $S D^{2}$ & Min.-Max. & M & $S D^{2}$ & Min.-Max. \\
\hline Linoleic fatty acid (g) & 13.24 & $6.75^{\mathrm{a}}$ & $1.33-41.13$ & 14.09 & $6.02^{\mathbf{b}}$ & $3.40-41.14$ & 14.01 & $6.61^{\mathrm{ab}}$ & $3.17-50.42$ \\
\hline$\alpha$-linolenic fatty acid (g) & 1.73 & $0.85^{\mathrm{a}}$ & $0.14-5.57$ & 1.83 & $0.71^{\mathrm{ab}}$ & $0.37-4.43$ & 1.86 & $0.85^{\mathbf{b}}$ & $0.37-6.97$ \\
\hline Linoleic/ $\alpha$-linolenic ratio & 7.78 & $1.77^{\mathrm{a}}$ & $2.72-26.59$ & 7.71 & $1.38^{\mathrm{a}}$ & $4.17-14.29$ & 7.68 & $2.24^{\mathrm{a}}$ & $3.70-34.19$ \\
\hline
\end{tabular}

Note: ${ }^{1}$ Data on the two cohorts of pregnant women (A and B) together; ${ }^{2}$ Means followed by the same letter do not differ according to the means difference test.

M: Mean; SD: Standard Deviation; Min.: Minimum; Max.: Maximum.

\section{DISCUSSION}

The average total lipids intake was within the recommendations in terms of its percentage contribution to diet energy. However, onethird of the diets did not reach the daily recommendation for intake of alpha-linolenic fatty acids and almost all diets presented a high ratio between linoleic and alpha-linolenic fatty acids. Overweight pregnant women of lower socioeconomic status are more likely to have inadequate intake of alpha-linolenic acid, regardless of the gestational trimester or the cohort. The intake of polyunsaturated fatty acids increased slightly from the first to the second trimester and remained unchanged in the third trimester.

The alpha-linolenic fatty acid intake of pregnant women was lower than that reported for pregnant adolescents studied in Rio de Janeiro [6]. Compared to another study conducted in Rio de Janeiro, the women in this study presented a less favorable profile, in respect of the intake of alpha-linolenic fatty acid, with a median and interquartile range of $1.63(1.25-2.19)$ grams versus 2.1 (1.4-2.6) grams [8]. The background social context is relevant to the intake of these nutrients, possibly through consideration of specific culinary cultures. Localized studies should aim to focus on pertinent nutritional interventions in prenatal care.

Compared to a study evaluating pregnant women in Southern India $(n=1,838)$ with predominantly vegetarian diets very low in saturated fat and total fats, the situation in Botucatu, as revealed in our study, was more favorable. The average energy percentage of alpha-linolenic fatty acid intake in pregnant women in Southern India was reported to be $0.24 \%$, compared to $0.86 \%$ in our study. The energy contribution of saturated fatty acids was also higher in the pregnant women in our study (10.4\% versus $8.4 \%)$. The low intake of these 
Table 4. Logistic regression analyses between characteristics of pregnant women and intake of alpha-linolenic acid above adequate intake. Botucatu (SP), 2012-2014.

\begin{tabular}{|c|c|c|c|c|c|c|}
\hline \multirow{2}{*}{ Variables } & \multicolumn{3}{|c|}{ Initial model ${ }^{1}$} & \multicolumn{3}{|c|}{ Final mode ${ }^{2}$} \\
\hline & OR & $95 \% \mathrm{Cl}$ & $p$-value & OR & $95 \% \mathrm{Cl}$ & $p$-value \\
\hline Age (years) & & & 0.352 & & & \\
\hline $20-30$ & 1 & & & & & \\
\hline$>30$ & 1.254 & $0.821-1.918$ & & & & \\
\hline $18-19$ & 1.418 & $0.883-2.276$ & & & & \\
\hline Level of education (years) & & & 0.023 & & & \\
\hline$\geq 11$ & 1 & & & & & \\
\hline $8-11$ & 1.395 & $1.005-1.937$ & & & & \\
\hline$<8$ & 1.579 & $1.102-2.262$ & & & & \\
\hline Socioeconomic classification & & & 0.014 & & & 0.019 \\
\hline B & 0.664 & $0.388-1.138$ & & 0.737 & $0.424-1.282$ & \\
\hline C & 0.605 & $0.431-0.848$ & & 0.609 & $0.430-0.861$ & \\
\hline $\mathrm{D} / \mathrm{E}$ & 1 & & & 1 & & \\
\hline Works outside the home & & & 0.074 & & & \\
\hline Yes & 1 & & & & & \\
\hline No & 1.298 & $0.975-1.730$ & & & & \\
\hline Lives with a partner & & & 0.518 & & & \\
\hline Yes & 1 & & & & & \\
\hline No & 0.900 & $0.653-1.240$ & & & & \\
\hline Number of births & & & 0.470 & & & \\
\hline 0 & 1 & & & & & \\
\hline 1 & 1.092 & $0.773-1.542$ & & & & \\
\hline$\geq 2$ births & 1.232 & $0.883-1.719$ & & & & \\
\hline White skin color & & & 0.046 & & & \\
\hline Yes & 1 & & & & & \\
\hline No & 1.342 & $1.006-1.792$ & & & & \\
\hline Use of tobacco before pregnancy & & & 0.053 & & & \\
\hline No & 1 & & & & & \\
\hline Yes & 1.368 & $0.996-1.879$ & & & & \\
\hline Alcohol consumption before pregnancy & & & 0.698 & & & \\
\hline No & 1 & & & & & \\
\hline Yes & 0.945 & $0.708-1.260$ & & & & 0.003 \\
\hline Pre-gestational nutritional status & & & 0.003 & & & \\
\hline Normal weight & 1 & & & 1 & & \\
\hline Underweight & 1.182 & $0.839-1.665$ & & 1.187 & $0.837-1.681$ & \\
\hline Overweight & 2.059 & $1.408-3.011$ & & 2.080 & $1.414-3.061$ & \\
\hline
\end{tabular}

Note: ${ }^{1}$ Model that included cohort and trimester and each of the maternal characteristics investigated separately; ${ }^{2}$ Multivariate final model that included cohort, trimester and maternal characteristics, socioeconomic status and pre-gestational status. Level of education $(p=0.46)$, work $(p=0.31)$, tobacco use $(p=0.20)$ and white skin color $(p=0.10)$ were excluded, which did not remain statistically significant in the multivariate analysis.

OR: Odds Ratio; $95 \% \mathrm{Cl}$ : 95\% Confidence Interval.

two fatty acids was associated with an increased risk of low birth weight infants in the Southern Indian study population [18]. On the other hand, comparing the diet of omnivores and vegetarians, an inner-city study on adults in the São Paulo region found a higher intake of polyunsaturated fatty acids among the vegetarian population [19]. Thus, national studies to investigate the intake of omega-3 polyunsaturated fatty acid and the balance between omega- 3 and omega- 6 intake, in subgroups of pregnant women with different eating styles, are required. 
Given the possible adverse effects of insufficient omega-3 intake and the potential benefits of the recommended intake of this nutrient, the situation in Botucatu is concerning for approximately one-third of the pregnant women, given the percentage with a low intake of alpha-linolenic acid, and suggests a public health issue to be addressed.

An important contribution of the present study was the identification of certain maternal characteristics associated with a higher chances of inadequate alpha-linolenic intake (pregestational excess weight and low socioeconomic level), allowing the identification of priority groups to facilitate interventions promoting the intake of this fatty acid. An inverse association between socioeconomic level and intake of alpha-linolenic acid was also detected in pregnant Mexican women with diets comprising a lipid profile close to that of the pregnant women from Botucatu. In Mexico, as in Brazil, access to food sources of omega-3 fatty acids appears linked to economic constraints [20], a factor to be considered when selecting foods to encourage intake of omega-3 fatty acids.

Of the total amount of alpha-linolenic fatty acid ingested by all pregnant women in all trimesters, foods eaten daily requiring oil for their preparation provided the greatest intake, with $14.8 \%$ derived from rice consumption, $8.0 \%$ from beans, and $7.7 \%$ from whole milk. Foods rich in alpha-linolenic acid, such as fish [21], do not form part of the diet in our study population.

Pre-gestational obesity, present in 18\% of pregnant women in the Botucatu cohorts, increases the risk of gestational diabetes [22], preterm delivery [23], pre-eclampsia, and other hypertensive syndrome disorders [24]. The finding that these women had a lower intake of alphalinolenic acid opens new areas of inquiry into the pathophysiological mechanisms of pregestational obesity and the possible adverse outcomes in pregnant woman.

According to the Brazilian food guide [25], a varied diet (with all groups and types of food), and with a low consumption of ultraprocessed foods, is able to meet all nutritional needs and still protect individuals against chronic diseases and obesity, being always preferable to the adoption of supplements. This document reinforces the idea that pregnant women should receive information promoting healthy eating in general and the intake of food sources rich in omega-3 fatty acids in particular, and not the supply or prescription of supplements. Not prescribing supplements is also reinforced by a systematic review, which indicated the need for further studies before making decisions on such practice [26].

The median of the ratio between linoleic and alpha-linolenic fatty acids in pregnant women in Botucatu, 7.50 (6.9-8.2), approached that reported by da Rocha \& Kac [8] for women from Rio de Janeiro: 7.7 (6.7-8.2). In the latter, there was an association between a ratio above 9:1 and postpartum depression. It is also important to highlight that most of the pregnant women studied did not use oils richer in alphalinolenic acid, such as canola and linseed. The vegetable oil most consumed by this population is soybean.

There are some limitations in the present study such as the use of a table not specific to a Brazilian setting to evaluate the intake of lipids, since the content of fatty acids, as well as other nutrients, is externally influenced by food, for example, supplied to animals that are ultimately ingested. The software used in the calculations is applied consistently in food consumption evaluation studies, and it favors comparison between studies in different countries. There is also a lack of data on the use of supplements, however, all pregnant women studied received prenatal primary health care, where only folic acid and iron are prescribed [13].

Common to quantitative evaluation of food consumption studies, challenges are faced in relation to the accuracy of the data obtained [27]. Many studies use the food frequency questionnaire and, in our study, the application 
of two 24hR in each gestational trimester offered a degree of methodological quality assurance. Food data collection was carefully described to ensure the best possible quality of such data.

Investigating food consumption during pregnancy led us to conclude that the effects of dietary changes during pregnancy on the intake of lipids in general and of fatty acids in particular are limited. Nevertheless, the analyses on factors associated with intake below the recommendation of alpha-linolenic fatty acids were adjusted by gestational trimester. They were also adjusted by cohort, in order to minimize any possible effect of the intervention previously conducted by the professionals who assisted to the cohort a pregnant women. This precaution supports the internal validity of our results, reducing the chances of bias.

\section{CONCLUSION}

The lipid profile of the diet of the pregnant women evaluated agreed with the recommendations in terms of total lipid intake and percentage contribution to dietary energy. On the other hand, one-third of the analyzed diets were below the recommended daily intake of alpha-linolenic acid. Inadequate alphalinolenic acid intake was greater among obese pregnant women of lower socioeconomic status, regardless of the gestational trimester and cohort. These results support interventions to promote the intake of foods that are rich sources of omega-3 fatty acids, in prenatal care, with special attention for women with pre-gestational excess weight and lower socioeconomic status, who have a higher risk of an inadequate intake of these acids.

\section{COLABORATORS}

LG VASCONCELOS, MABL CARVALHAES and CB GOMES participated in the conception and design, data analysis and interpretation, revision and approval of the definitive version of the article. MB MALTA participated in the conception and design, revision and approval of the definitive version of the article. I DICHI and MHD'A BENÍCIO participated in the data analysis and interpretation, revision and approval of the definitive version of the article.

\section{REFERE N CES}

1. Procter SB, Campbell CG. Position of the academy of nutrition and dietetics: Nutrition and lifestyle for a healthy pregnancy outcome. J Acad Nutr Diet. 2014;114(7):1099-103. https://doi.org/10.1016/j. jand.2014.05.005

2. Al MDM, Van Houwelingen AC, Kester ADM, Hasaart TH, de Jong AEP, Hornstra G. Maternal essential fatty acid patterns during normal pregnancy and their relationship to the neonatal essential fatty acid status. Br J Nutr. 1995;74(1):5568. https://doi.org/10.1079/BJN19950106

3. Escobar J, Estrada L, Gómez L, Gil AM, Cadavid A. ¿Pueden los ácidos grasos omega 3 y 6 contrarrestar los efectos negativos de la obesidad en la gestación? Rev Chil Obstet Ginecol. 2013;78(3):244-50.

4. Instituto Brasileiro de Geografia e Estatística. Pesquisa de orçamentos familiares 2008-2009: análise do consumo alimentar pessoal no Brasil. Rio de Janeiro: IBGE; 2011.

5. Meher A, Randhir K, Mehendale S, Wagh G, Joshi $S$. Maternal fatty acids and their association with birth outcome: A prospective study. PLoS One. 2016;11:e0147359. https://doi.org/10.1371/ journal.pone.0147359

6. Campos ABF, Pereira RA, Queiroz J, Saunders C. Ingestão de energia e de nutrientes e baixo peso ao nascer: estudo de coorte com gestantes adolescentes. Rev Nutr. 2013;26(5):551-61. https:// doi.org/10.1590/S1415-52732013000500006

7. Golding J, Steer C, Emmett P, Davis JM, Hibbeln JR. High Levels of depressive symptoms in pregnancy with low omega-3 fatty acid intake from fish. Epidemiology. 2009;20(4):598-603. https://doi. org/10.1097/EDE.0b013e31819d6a57

8. da Rocha CMM, Kac G. High dietary ratio of omega- 6 to omega-3 polyunsaturated acids during pregnancy and prevalence of post-partum depression. Mater Child Nutr. 2012;8(1):36-48. https://doi.org/10.1111/j.17408709.2010.00256.x

9. Ramakrishnan U, Gonzalez-Casanova I, Schnaas L, DiGirolamo A, Quezada AD, Pallo BC, et al. Prenatal supplementation with DHA improves attention at 5 y of age: A randomized controlled 
trial. Am J Clin Nutr. 2016;104(4):1075-82. https:// doi.org/10.3945/ajen.114.101071

10. Barbieri P, Crivellenti LC, Nishimura RY, Sartorelli DS. Validation of a food frequency questionnaire to assess food group intake by pregnant women. J Hum Nutr Diet. 2015;28(Suppl.1):38-44. https:// doi.org/10.1111/jhn.12224

11. Bertin RL, Parisenti J, Di Pietro PF, Vasconcelos FDAG. Métodos de avaliação do consumo alimentar de gestantes: uma revisão. Rev Bras Saúde Mater Infant. 2006;6(4):383-90. https://doi.org/10. 1590/S1519-38292006000400004

12. Malta MB, Carvalhaes MABL, Takito MY, Tonete VLP, Barros AJD, Parada CMGL, et al. Educational intervention regarding diet and physical activity for pregnant women: Changes in knowledge and practices among health professionals. BMC. 2016;16(1):175. https://doi.org/10.1186/s12884016-0957-1

13. Ministério da Saúde (Brasil). Atenção ao pré-natal de baixo risco. Brasília: Ministério da Saúde; 2012.

14. Moshfegh AJ, Rhodes DG, Baer DJ, Murayi T, Clemens JC, Rumpler WV, et al. The US Department of Agriculture Automated MultiplePass Method reduces bias in the collection of energy intakes. Am J Clin Nutr. 2008;88(2):324-32.

15. Padovani RM, Amaya-Farfán J, Colugnati $F A B$, Domene SMA. Dietary reference intakes: aplicabilidade das tabelas em estudos nutricionais. Rev Nutr. 2006;19(6):741-60. https://doi.org/10. 1590/S1415-52732006000600010

16. Fisberg RM, Slater B, Marchioni DML, Martini LA. Inquéritos alimentares: métodos e bases científicos. Barueri: Manole; 2005.

17. Institute of Medicine. Dietary Reference Intakes for energy, carbohydrate, fiber, fat, fatty acids, cholesterol, protein, and amino acids. Washington (DC): National Academics Press; 2005.

18. Mani I, Dwarkanath P, Thomas T, Thomas A, Kurpad A V. Maternal fat and fatty acid intake and birth outcomes in a South Indian population. Int J Epidemiol. 2016;45(2):523-31. https://doi. org/10.1093/ije/dyw010
19. Ribeiro MF, Beraldo RA, Touso MFDS, Vassimon HS. Ingestão alimentar, perfil bioquímico e estado nutricional entre vegetarianos e não vegetarianos. Rev Arq Ciênc Saúde. 2015;22(3):58-63. https:// doi.org/10.17696/2318-3691.22.3.2015.239

20. Parra-Cabrera S, Stein AD, Wang M, Martorell R, Rivera J, Ramakrishnan U. Dietary intakes of polyunsaturated fatty acids among pregnant Mexican women. Matern Child Nutr. 2011;7:140-7. https://doi.org/10.1111/j.1740-8709.2010.00254.x

21. Martin CA, Almeida VV, Ruiz MR, Visentainer JEL, Matshushita M, Souza NE de, et al. Ácidos graxos poliinsaturados ômega-3 e ômega-6: importância e ocorrência em alimentos. Rev Nutr. 2006;19(6):761-70. https://doi.org/10.1590/S14 15-52732006000600011

22. Chu SY, Callaghan WM, Kim SY, Schmid CH, Lau J, England LJ, et al. Maternal obesity and risk of gestational diabetes Mellitus. Diabetes Care. 2007;30(8):2070-6. https://doi.org/10.2337/dc06-2 $559 a$

23. Bodnar LM, Parks WT, Perkins K, Pugh SJ, Platt RW, Feghali $M$, et al. Maternal prepregnancy obesity and cause-specific stillbirth. Am J Clin Nutr. 2015;102(4):858-64. https://doi.org/10.3945/ajcn. 115.112250

24. Jeyabalan A. Epidemiology of preeclampsia: Impact of obesity. Nutr Rev. 2013;71(1):S18-25. https://doi.org/10.1111/nure.12055

25. Ministério da Saúde (Brasil). Guia alimentar para a população brasileira. Brasília: Ministério da Saúde; 2014.

26. Saccone G, Saccone I, Berghella V. Omega-3 long-chain polyunsaturated fatty acids and fish oil supplementation during pregnancy: Which evidence? J Mater Neonatal Med. 2015;29(15):1-9. https://doi.org/10.3109/14767058.2015.1086742

27. Anjos LA, Souza DR, Rossato SL. Desafios na medição quantitativa da ingestão alimentar em estudos populacionais. Rev Nutr. 2009;22(1):151-61. https://doi.org/10.1590/S1415-52732009000100 014
Received: January 13, 2017 Final version: March 20, 2017 Approved: May 5, 2017 
